\title{
On the Meteorological Elements' Distribution in the Region of the Typhoon (I)
}

\author{
By S. Tomitaka \\ Fukuoka Meteorological Observatory \\ (Manuscript received 18 April 1960)
}

\begin{abstract}
A formula of gradient wind velocity and relative vorticity for typhoon is derived, assuming that the pressure distribution at sea level is circular in the region of typhoon.

And the distribution of the wind velocity is derived by introducing the values from the above-mentioned formula to the general solution of equation of motion in the frictional layer as the function of the height and the distance from the center.

The height of frictional influence and the value of the other elements are estimated for the region of the typhoon.

These calculating methods are tested with the synoptic data about the Typhoon No. 12 (June) which invaded Kyushu district in the year 1954.
\end{abstract}

\section{Introduction}

The lives of several thousand peoples and the materials of hundred milliard yen were deprived by an inversion of violent Typhoon Isewan at Nagoya district in a night last year.

We can not but be astonished how mighty is Natures' violence now.

From a view point of preventing the disasters, the study of typhoon became important increasingly in the recent years.

In the first stage, it was pointed out by Dr. Okada, Dr. Fujiwara Dr. Horiguchi and Dr. Namekawa being responded by many students and the excellent researchs have been performed in the late years in our country. While, the Meteorological Agency installed an electronic calculating machine last year.

And so, the numerical prediction of the typhoon course is expected to develope largely and rapidly.

In this reports, firstly, it is endeavoured to get the equation of pressures' distribution correctly, as Dr. Horiguchi, Dr. Takahashi, Dr. Fujita and Mr. Masuda derived already.

Secondary, the author got the equation of gradients' wind velocity and relative vorticity using the equations of pressures' distribution obtained firstly.
The general solution of the equation about the motion of atmosphere with frictional layer has already been derived by Dr. Syono. Here, the equation is expressed by a cylindrical coordinate, being assumed stationary, and is balanced with Coriolis force, pressures' gradient and frictional force.

Then, the distribution of wind velocity in the region of the typhoon can be obtained as the function of height $z$ and the distance from the center $r$, by introducing above-cited relative vorticity and gradient wind velocity to these general solution.

And using the values thus obtained, the distribution of horizontal divergence, ascentional rate and eddy precipitation can be obtained as the function of height $z$ and the distance from the center $r$ too.

It is very convenient for these methods that the observed data of sea level pressure is more numerous than the data of upper layers, and that aircraft observation is enforced for every typhoons about the centers' position and pressure, wind velocity, etc.

2. Theoretical considerations for the distributions of each meteorological element in the region of typhoon

A distribution of pressure in the region of typhoon is assumed generally shown by, 


$$
p(r)=p(\infty)-\frac{\Delta p}{n} \sum_{j=1}^{n} a_{j} \exp \left(-\frac{r^{m}}{r_{j}^{m}}\right),
$$

where, $p(r)$ : pressure in the distance of $r$, $p(\infty)$ : pressure of undisturbed environment,

$\Delta p:$ the depth of the pressure in the center,

$a_{j}, r_{j}, m, n:$ constants which decide the form of pressure distribution in the region of typhoon.

Differentiating the equation (1) in respect of $r$, we have,

$$
\frac{\partial p(r)}{\partial r}=\frac{\Delta p}{n} \sum_{j=1}^{n} a_{j} m \frac{r^{m-1}}{r_{j}^{m}} \exp \left(-\frac{r^{m}}{r_{j}^{m}}\right)
$$

generally, the gradient wind velocity $v_{g}$ is given as,

$$
v_{g}=-\frac{1}{2} f r+\left\{\left(\frac{1}{2} f r\right)^{2}+\frac{r}{\rho}\left(\frac{\partial p}{\partial r}\right)\right\}^{\frac{1}{2}}
$$

where, $f=2 \omega \sin \varphi$ : Coriolis parameter, $\omega=7.29 \cdot 10^{-5} \mathrm{rad} \mathrm{sec}^{-1}$ : angular velocity of rotation of the earth,

$\rho:$ density of air.

Substituting (2) into (3), we have,

$$
\begin{aligned}
v_{g}= & -\frac{1}{2} f r+\left[\left(\frac{1}{2} f r\right)^{2}+\frac{\Delta p}{\rho n} \sum_{j=1}^{n} a_{j} m\left(\frac{r}{r_{j}}\right)^{m}\right. \\
& \left.\times \exp \left(-\frac{r^{m}}{r_{j}^{m}}\right)\right]^{\frac{1}{2}} .
\end{aligned}
$$

Neglecting the higher order, the relative vorticity $\zeta$ is,

$$
\zeta=\frac{\partial V}{\partial r}+\frac{V}{r} .
$$

Consequently, the relative gradient vorticity $\zeta_{g}$ would be,

$$
\begin{aligned}
\zeta_{g}= & -f+\left[\left(\frac{1}{2} f r\right)^{2}+\frac{\Delta p}{\rho n} \sum_{j=1}^{n} a_{j} m\left(\frac{r}{r_{j}}\right)^{m}\right. \\
& \left.\times \exp \left(-\frac{r^{m}}{r_{j}^{m}}\right)\right]^{-\frac{1}{2}} \\
& \times\left[\frac{1}{2} f^{2} r+\frac{\Delta p}{\rho n} \sum_{j=1}^{n} a_{j} m \frac{r^{m-1}}{r_{j}^{m}}\right. \\
& \left.\times\left\{1+\frac{m}{2}-\frac{m r^{m}}{2 r_{j}^{m}}\right\} \exp \left(-\frac{r^{m}}{r_{j}^{m}}\right)\right] .
\end{aligned}
$$

Then, a simplified case of above-stated equations shall be considered;

(i) if we put these constants as $n=1$, $a_{1}=1, m=1, r_{1}=N$, then equations (1), (4) and (6) would be deduced to,

$$
\frac{\Delta p(r)}{\Delta p}=\exp \left(-\frac{r}{N}\right)
$$

$v_{g I}=-\frac{1}{2} f r+\left[\left(\frac{1}{2} f r\right)^{2}+\frac{\Delta p}{\rho} \frac{r}{N} \exp \left(-\frac{r}{N}\right)\right]^{\frac{1}{2}},(8)$ and,

$$
\begin{aligned}
\zeta_{g I}= & -f+\left[\left(\frac{1}{2} f r\right)^{2}+\frac{\Delta p}{\rho} \frac{r}{N} \exp \left(-\frac{r}{N}\right)\right]-\frac{1}{2} \\
& \times\left[\frac{1}{2} f^{2} r+\frac{\Delta p}{2 \rho N}\left(3-\frac{r}{N}\right) \exp \left(-\frac{r}{N}\right)\right]
\end{aligned}
$$

(ii) if we put these constants as $n=2$, $a_{1}=a_{2}=1, r_{1}=L, r_{2}=M, m=2$, then equations (1), (4) and (6) would be deduced to,

$$
\begin{aligned}
\frac{\Delta p(r)}{\Delta p} & =\frac{1}{2}\left\{\exp \left(-\frac{r^{2}}{L^{2}}\right)+\exp \left(-\frac{r^{2}}{M^{2}}\right)\right\} \\
v_{g I I}= & -\frac{1}{2} f r+\left[\left(\frac{1}{2} f r\right)^{2}+\frac{\Delta p}{\rho}\right. \\
& \times\left\{\left(\frac{r}{L}\right)^{2} \exp \left(-\frac{r^{2}}{L^{2}}\right)\right. \\
& \left.\left.+\left(\frac{r}{M}\right)^{2} \exp \left(-\frac{r^{2}}{M^{2}}\right)\right\}\right]^{\frac{1}{2}}
\end{aligned}
$$

and,

$$
\begin{aligned}
\zeta_{g I I}= & -f+\left[\left(\frac{1}{2} f r\right)^{2}+\frac{\Delta p}{\rho}\left\{\left(\frac{r}{L}\right)^{2} \exp \left(-\frac{r^{2}}{L^{2}}\right)\right.\right. \\
& \left.\left.+\left(\frac{r}{M}\right)^{2} \exp \left(-\frac{r^{2}}{M^{2}}\right)\right\}\right]^{-\frac{1}{2}} \\
& \times\left[\frac{1}{2} f^{2} r+\frac{\Delta p}{\rho}\left\{\left(\frac{r}{L}\right)^{2}\left(\frac{2}{r}-\frac{r}{L^{2}}\right)\right.\right. \\
& \times \exp \left(-\frac{r^{2}}{L^{2}}\right)+\left(\frac{r}{M}\right)^{2}\left(\frac{2}{r}-\frac{r}{M^{2}}\right) \\
& \left.\left.\times \exp \left(-\frac{r^{2}}{M^{2}}\right)\right\}\right]
\end{aligned}
$$

On the other hand, if the motion is assumed to be stationary and axial symmetry, the equation of motion in cylindrical coodinates with frictional layer ranging between a few tens meters and 1 to 2 kilometers above the ground will be given as,

$$
\left.\begin{array}{c}
-(f+\zeta) v_{\theta}=-\frac{1}{\rho} \frac{\partial P}{\partial r}+\nu \frac{\partial^{2} v_{r}}{\partial z^{2}} \\
(f+\zeta) v_{r}=\nu \frac{\partial^{2} v_{\theta}}{\partial z^{2}}
\end{array}\right\},
$$

where $\nu$ : eddy frictional coefficient,

$$
P=p+\frac{1}{2} \rho\left(v_{r}^{2}+v_{\theta}^{2}\right),
$$

$z$ : height.

The wind at higher level is assumed to approach to gradient wind, and the average vorticity, averaged from surface to the height of frictional influence is used.

In this case, Dr. Syono has derived the general solution of this equation of motion with frictional layer. 
Then Syonos' solutions are,

(a) first case $u=v=0$ at $z=0$, then

$$
\left.\begin{array}{l}
v_{r}=-v_{g} \exp \left(-\frac{\pi}{D} z\right) \sin \left(\frac{\pi}{D} z\right) \\
v_{\theta}=v_{g}\left[1-\exp \left(-\frac{\pi}{D} z\right) \cos \left(\frac{\pi}{D} z\right)\right]
\end{array}\right\},
$$

where,

$$
\begin{gathered}
\bar{\zeta}=\frac{1}{\bar{D}} \int_{0}^{\bar{D}} \zeta d z=0.827 \zeta_{g}, \\
D=\pi \sqrt{\frac{2 \nu}{f+\bar{\zeta}}}
\end{gathered}
$$

(b) second case, $u=\chi \frac{\partial u}{\partial z}, v=\chi \frac{\partial v}{\partial z}$ at $z=0$, then

$$
\left.\begin{array}{l}
v_{r}=-v_{g} C \exp \left(-\frac{\pi}{D} z\right) \cos \left(\frac{\pi}{D} z-\alpha\right) \\
v_{\vartheta}=v_{g}\left[1+C \exp \left(-\frac{\pi}{D} z\right) \sin \left(\frac{\pi}{D} z-\alpha\right)\right]
\end{array}\right\},
$$

where

$$
\begin{gathered}
C=\sin \alpha-\cos \alpha \\
=\left[1+2 \chi \sqrt{\frac{f+\bar{\zeta}}{2 \nu}}+\chi^{2} \frac{f+\bar{\zeta}}{\nu}\right]^{-\frac{1}{2}}, \\
\tan \alpha=\frac{1+x \sqrt{\frac{f+\bar{\zeta}}{2 \nu}}}{x \sqrt{\frac{f+\bar{\zeta}}{2 \nu}}},
\end{gathered}
$$

$\bar{\zeta}=\frac{1}{\bar{D}} \int_{0}^{\bar{D}} \zeta d z=[1-0.173 C(\sin \alpha-\cos \alpha)] \zeta_{g}$.

Then, the followings are put in order to abbreviate the calculation,

$$
\begin{aligned}
& \frac{\Delta p}{n} \sum_{j=1}^{n} a_{j} \exp \left(-\frac{r^{m}}{r_{j}^{m}}\right) \\
& \quad=X\left(\Delta p, n, a_{j}, r_{j}, m, r\right), \\
& \frac{\Delta p}{n} \sum_{j=1}^{n} a_{j} m\left(\frac{r}{r_{j}}\right)^{m} \exp \left(-\frac{r^{m}}{r_{j}^{m}}\right) \\
& \quad=Y\left(\Delta p, n, a_{j}, r_{j}, m, r\right), \\
& \frac{\Delta p}{n} \sum_{j=1}^{n} a_{j} m \frac{r^{m-1}}{r_{j}^{m}}\left\{1+\frac{m}{2}-\frac{m r^{m}}{2 r_{j}^{m}}\right) \exp \left(-\frac{r^{m}}{r_{j}^{m}}\right) \\
& \quad=Z\left(\Delta p, n, a_{j}, r_{j}, m, r\right) .
\end{aligned}
$$

In this case, eqs. (1), (3), (6), (15) and (16) would be deduced to,

$$
\begin{aligned}
p(r)= & p(\infty)-X, \\
v_{g}= & -\frac{1}{2} f r+\left[\left(\frac{1}{2} f r\right)^{2}+\frac{Y}{\rho}\right]^{\frac{1}{2}}, \\
\zeta_{g}= & -f+\left[\left(\frac{1}{2} f r\right)^{2}+\frac{Y}{\rho}\right]^{-\frac{1}{2}} \cdot\left[\frac{1}{2} f^{2} r+\frac{Z}{\rho}\right], \\
\bar{\zeta}_{1}= & 0.827\left[-f+\left\{\left(\frac{1}{2} f r\right)^{2}+\frac{Y}{\rho}\right\}^{-\frac{1}{2}}\right. \\
& \left.\times\left(\frac{1}{2} f^{2} r+\frac{Z}{\rho}\right)\right],
\end{aligned}
$$

$$
\begin{aligned}
D_{1}= & \sqrt{2 \nu} \pi\left[0.173 f+0.827\left\{\left(\frac{1}{2} f r\right)^{2}+\frac{Y}{\rho}\right\}^{-\frac{1}{2}}\right. \\
& \left.\times\left(\frac{1}{2} f^{2} r+\frac{Z}{\rho}\right)\right]^{-\frac{1}{2}}
\end{aligned}
$$

and eq. (14) is rewritten as,

$$
\left.\begin{array}{l}
v_{r I}=-v_{g} \exp \left(-\frac{\pi}{D_{1}} z\right) \sin \left(\frac{\pi}{D_{1}} z\right) \\
v_{\theta I}=v_{g}\left[1-\exp \left(-\frac{\pi}{D_{1}} z\right) \cos \left(\frac{\pi}{D_{1}} z\right)\right]
\end{array}\right\} .
$$

And $\alpha_{1}$ and $C_{1}$ are obtained from eqs. (18) and (19) using $\bar{\zeta}_{1}$ in eq. (27),

$$
\begin{aligned}
& \alpha_{1}= \tan ^{-1}\left[1+\frac{\sqrt{2 \nu}}{\chi}\left(f+\bar{\zeta}_{1}\right)^{-\frac{1}{2}}\right] \\
&= \tan ^{-1}\left\{1+\frac{\sqrt{2 \nu}}{\chi}[0.173 f+0.827\right. \\
& \times\left.\left.\left\{\left(\frac{1}{2} f r\right)^{2}+\frac{Y}{\rho}\right\}^{-\frac{1}{2}} \cdot\left(\frac{1}{2} f^{2} r+\frac{Z}{\rho}\right)\right]^{-\frac{1}{2}}\right),(30) \\
& C_{1}=\sin \alpha_{1}-\cos \alpha_{1},
\end{aligned}
$$

and so,

$$
\begin{aligned}
& \bar{\zeta}_{I I}=\left[1-0.173 C_{1}\left(\sin \alpha_{1}-\cos \alpha_{1}\right)\right] \zeta_{g}, \\
& \alpha_{I I}=\tan ^{-1}\left[1+\frac{\sqrt{2 \nu}}{\chi}\left(f+\bar{\zeta}_{I I}\right)^{-\frac{1}{2}}\right], \\
& C_{I I}=\sin \alpha_{I I}-\cos \alpha_{I I}, \\
& D_{I I}=\pi \sqrt{2 \nu}\left(f+\bar{\zeta}_{I I}\right)^{-\frac{1}{2}},
\end{aligned}
$$

and so, eq. (17) is rewritten as,

$$
\left.\begin{array}{l}
v_{r I I}=-v_{g} C_{I I} \exp \left(-\frac{\pi}{D_{I I}} z\right) \cos \left(\frac{\pi}{D_{I I}} z-\alpha_{I I}\right) \\
v_{\theta I I}=v_{g}\left[1+C_{I I} \exp \left(-\frac{\pi}{D_{I I}} z\right) \sin \left(\frac{\pi}{D_{I I}} z-\alpha_{I I}\right)\right]
\end{array}\right\} .
$$

Here, the constants $a_{j}, m, n, r_{j}, \Delta p$ and $\varphi$ are decided already when the form of typhoons' pressure distribution is decided.

And so, the wind velocitiy distribution is obtained as the function of the height $z$ and the distance from the center $r$, by using the equations (29) and (36), and deciding the value of the surface wind condition $\chi$, eddies frictional coefficient $\nu$ and the dencity of air $\rho$ which vary considerably by height.

Tayler decided the value of $\nu$ at the layer of height 900 meter, using Debsons' observational data, as follows;

$6.2 \mathrm{~m}^{2} \mathrm{sec}^{-1}$ at a gale,

$5.0 \mathrm{~m}^{2} \mathrm{sec}^{-1}$ at a moderate wind,

$2.8 \mathrm{~m}^{2} \mathrm{sec}^{-1}$ at a light wind.

And it was recorded that the value of $\nu$ was evaluated as $0.077-0.69 \mathrm{~m}^{2} \mathrm{sec}^{-1}$ at an altitude 100-300 meter on the sea, by Scotiyas' boats 
(this name is uncertain).

Here, the calculation is tried using the value of $\nu$ as $50 \mathrm{~m}^{2} \mathrm{sec}^{-1}, 1 \mathrm{~m}^{2} \mathrm{sec}^{-1}, 0.5 \mathrm{~m}^{2}$ $\mathrm{sec}^{-1}, \quad 0.3 \mathrm{~m}^{2} \mathrm{sec}^{-1}$ and $0.1 \mathrm{~m}^{2} \mathrm{sec}^{-1}$, at the layer of height 500 meter from the surface.

And value of $\chi$, which decides surface wind condition, is assumed as $10 \mathrm{~m}, 50 \mathrm{~m}, 100 \mathrm{~m}$ and $200 \mathrm{~m}$.

Then, $50 \mathrm{~m}^{2} \mathrm{sec}^{-1}$ and $1 \mathrm{~m}^{2} \mathrm{sec}^{-1}$ as the value of $\nu$ are found not suitable, because the calculated wind velocity becomes too small at the lower layer.

And so, the value of $0.3 \mathrm{~m}^{2} \mathrm{sec}^{-1}$, which is suited for the present calculation, is used.

\section{The method of calculating the meteoro- logical elements in the typhoons' region, with an example}

The violent typhoon No. 12 (June) invaded Kyushu in the year 1954.

And she passed cutting Kyushu longitudinally, and gave enormous disasters.

The variation of the constants which decide the form of pressure distribution, vorticity, wind velocity, and the height of frictional influence, in the region of the typhoon, is examined.

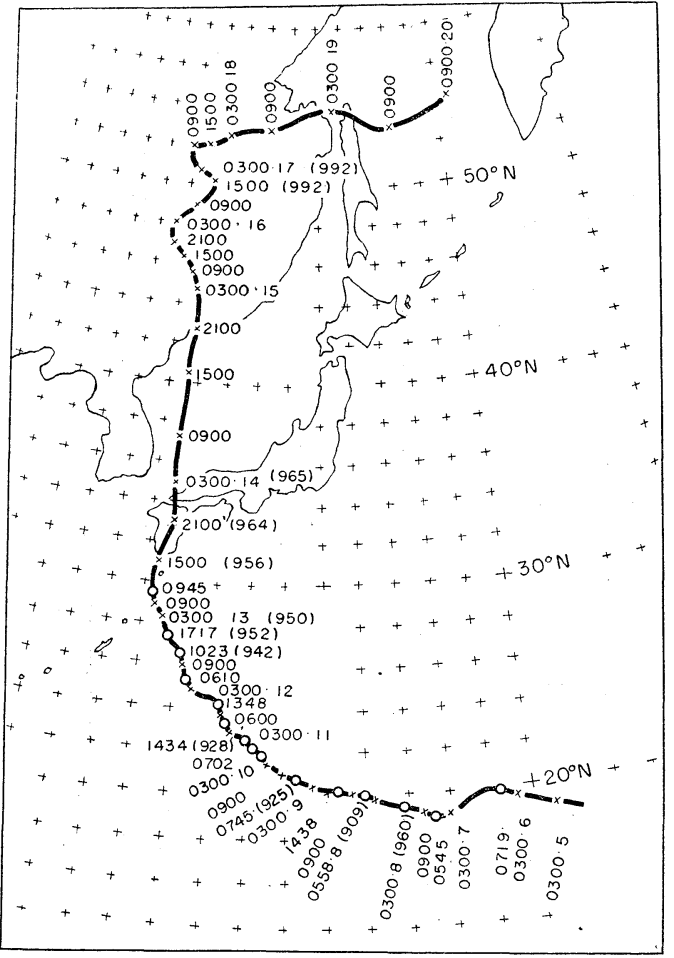

Fig. 1. The path of typhoon June with the date. $O$ and $x$ give the center position by the aircraft observation and by the synoptic analysis respectively, the value of center pressure being given in parenthesis.

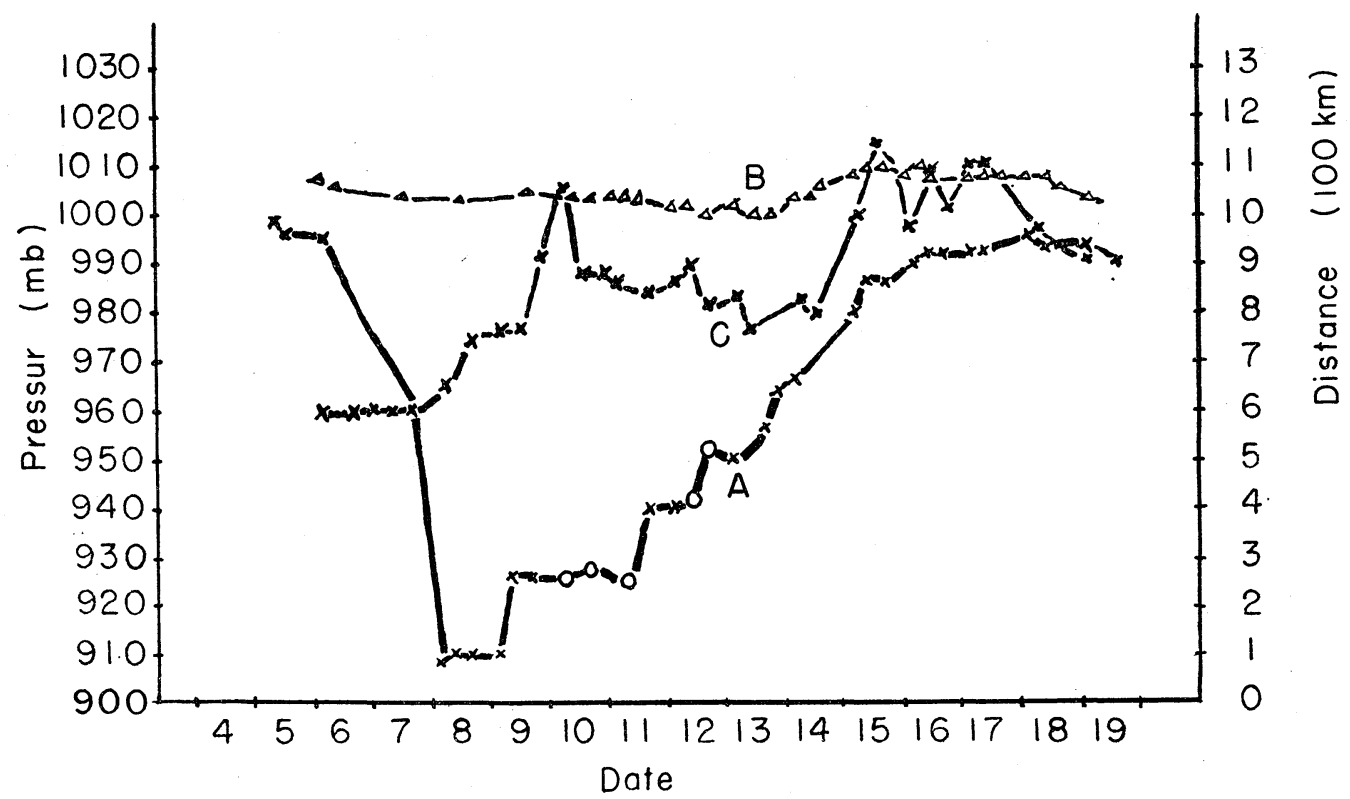

Fig. 2. The variations of the pressures at the center and the outsides, and the radius distance between the outside and the center for typhoon June. The notation is same as for Fig. 1.

A: the variation of the center pressure,

$B$ : the variation of the outside pressure,

$\mathrm{C}$ : the radius distance between the outside and the center. 
Fig. 1 shows the path of the typhoon June with the date.

Here, the symbol $\bigcirc$ is the centers' position by the aircraft observation, and the symbol $x$ is one by the synoptic analysis.

Typhoon June developed greatly while she was situated on the sea southeast of Kyushu, and the center pressure showed $909 \mathrm{mb}$ on $8-9$ th. But then, the centers' pressure depth became shallow, and the region of center was spread gradually.

Fig. 2 shows the relation between the variations of pressures at the center and the outside, and the distance between the outside and the center of this typhoon.

The typhoon is found decaying on the evening of 13th on landing onto the south part of Kyushu.

Fig. 3a shows the depth of centers' pressure $\Delta p$ and the state of its variation, during 6 th in generating to 18 th in decaying.
Fig. $3 \mathrm{~b}$ shows the state of variation $\frac{\Delta p(r)}{\Delta p}$, at $r=100 \mathrm{~km}, 300 \mathrm{~km}$ and $400 \mathrm{~km}$ respectively, where

$$
\begin{gathered}
\Delta p(r)=p(\infty)-p(r), \\
\Delta p=p(\infty)-p_{0} .
\end{gathered}
$$

$p_{0}$ : pressure at the typhoons' center.

It is found that the value of $\frac{\Delta p(r)}{\Delta p}$ was increased, according to that the centers' depth became shallow gradually, after landed onto Kyushu.

In this case, the value of $\frac{\Delta p_{300}}{\Delta p}$ and $\frac{\Delta p_{400}}{\Delta p}$ varied in larger extent than $\frac{\Delta p_{100}}{\Delta p}$.

Fig. $3 \mathrm{c}$ shows the changing state of the constants $L, M$ and $N$, which decide the form of the pressure distribution, property and decline of the typhoon, the pressure distribution of the typhoon being assumed indicated by eq. (7) or (10),

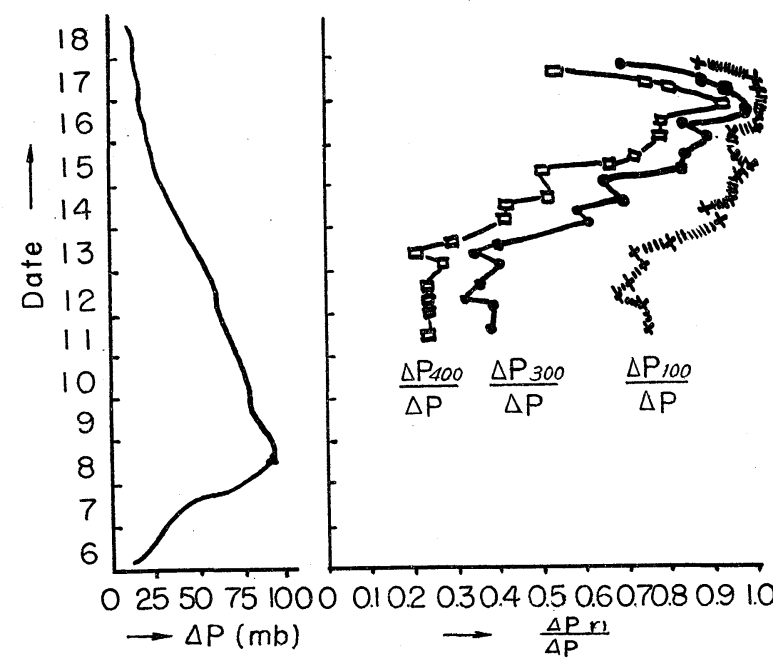

(a)

(b)

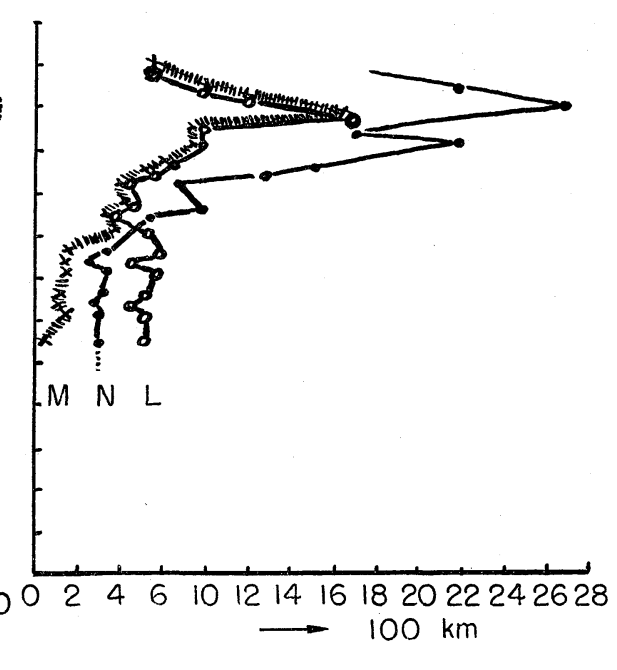

(c)

Fig. 3a. The variation of the center pressure depth $\Delta p$ in typhoon June.

Fig. 3b. The variation of $\frac{\Delta p_{400}}{\Delta p}, \frac{\Delta p_{300}}{\Delta p}, \frac{\Delta p_{100}}{\Delta p}$.

Fig. 3c. The variation of the constants $L, M$ and $N$ which decide the form of typhoon pressure distribution.

In the most developing period, the value of $L$ was about $500 \mathrm{~km}$ and $M 30 \mathrm{~km}$, and then the value of $M$ increased gradually after the typhoon struck the South Kyushu.

Then, both values became same magnitude, that is to say, the value of $M$ increased gradually and the both value became to lie one upon another.
And after, these values incresed to about $700 \mathrm{~km}$ or $900 \mathrm{~km}$.

Next, the pressure distribution was derived in good approximation applying equation (7) to this typhoon.

The value of $N$ was about $300 \mathrm{~km}$ on $11 \mathrm{th}$, then it increased to about $2,000-3,000 \mathrm{~km}$ gradually according to the declining. 


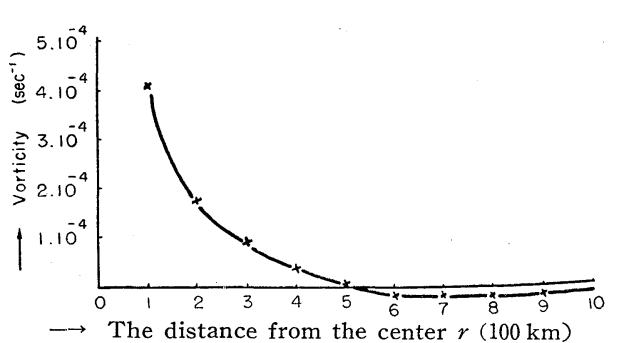

Fig. 4. The distribution of relative vorticity calculated by eq. (9), in the region of the typhoon June, at $0600 \mathrm{z} 12$ th.

Fig. 4 shows the distribution of relative vorticity calculated by eq. (9), in the region of this typhoon at $0600 \mathrm{z}$ September 12th.

Then, the large value of relative vorticity, $4 \cdot 10^{-4} \mathrm{sec}^{-1}$ at $r=100 \mathrm{~km}$, is obtained.

But the value decreases gradually with proceeding to outer region, becomes zero at $r=500 \mathrm{~km}$, and becomes negative and small value in the more outer region.

Here, the following values are used for calculations,

$$
\begin{aligned}
\text { density of air } \rho & \fallingdotseq 1.1 \cdot 10^{-3} \mathrm{~g} \mathrm{~cm}^{-3}, \\
\text { latitude } & =27^{\circ} \\
N & =r_{1}=300 \mathrm{~km}, \\
\Delta p & =60 \mathrm{mb} .
\end{aligned}
$$

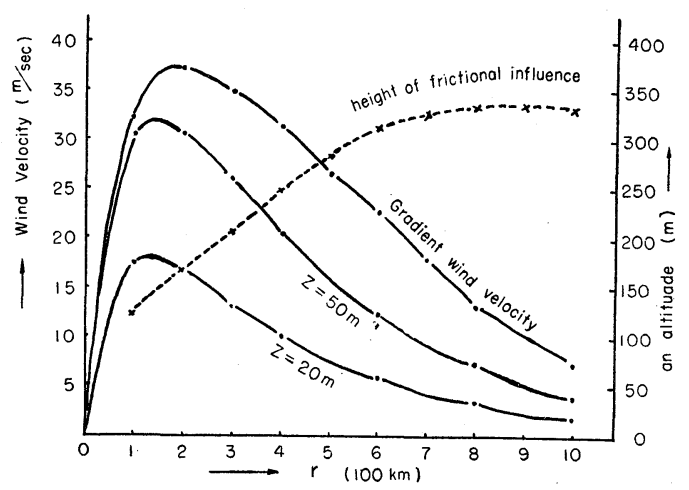

Fig. 5a. The distribution of calculated wind velocity in the region of typhoon June, as the function of $r$ and $z$, using the eq. (29), at $0600 \mathrm{z} 12$ th.

Here, the values, $a_{1}=1, m=1, n=1, r_{1}=300$ $\mathrm{km}, \varphi=27^{\circ}, \nu=0.3 \mathrm{~m}^{2} \mathrm{sec}^{-1}$ and $z=0 \mathrm{~m}, 20 \mathrm{~m}$, $50 \mathrm{~m}$ are used, and the height of fricitonal influence is given by eq. (28) too.

Fig. 5a shows the distribution of calculated wind velocity in the region of typhoon June, as the function of $r$ and $z$, using equation (29), at $0600 z$ September 12th.
Here, the values, $a_{1}=1, m=1, n=1, r_{1}=N$ $=300 \mathrm{~km}, \varphi=27^{\circ}, \nu=0.3 \mathrm{~m}^{2} \mathrm{sec}^{-1}$ and $z=0 \mathrm{~m}$, $20 \mathrm{~m}, 50 \mathrm{~m}$ are used. And the height of frictional influence is given by eq. (28) too.

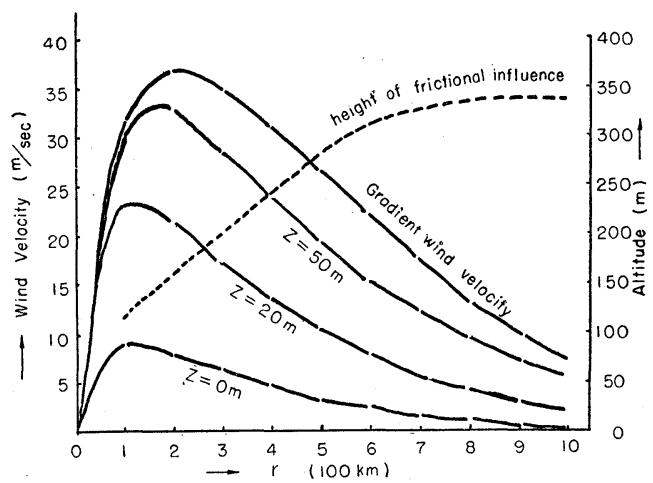

Fig. 5b. The distribution of calculated wind velocity and the height of frictional influence by eq. (36) and (35), as the function of $r$ and $z$, the constants used being same as in Fig. 5a except $x=10 \mathrm{~m}$.

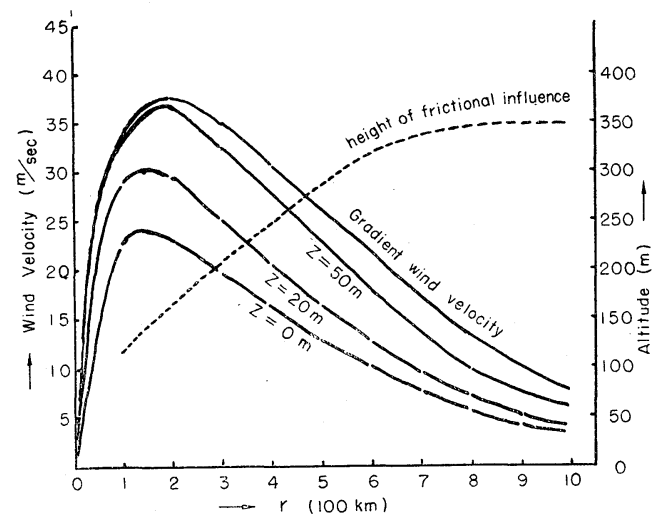

Fig. 5c. The same as Fig. 5b except $x=50 \mathrm{~m}$.

And Figs. $5 \mathrm{~b}$ and $5 \mathrm{c}$ show the calculated wind velocity and the height of frictional influence from eq. (36) and eq. (35) respective$1 y$, the same constants and condition as in Fig. 5a being used, except that the value of $\chi$ is $10 \mathrm{~m}$ and $50 \mathrm{~m}$ at Fig. $5 \mathrm{~b}$ and $5 \mathrm{c}$ respectively.

The distribution of the observed surfaces' wind velocity as the function of $r$ from the synoptic data, at $0600 \mathrm{z} 12 \mathrm{th}$, is shown in Fig. 6.

In this case, distinct tendency about the wind velocity distribution is not found owing to the scanty of synoptic data in the inner region of typhoon, though the data in the 


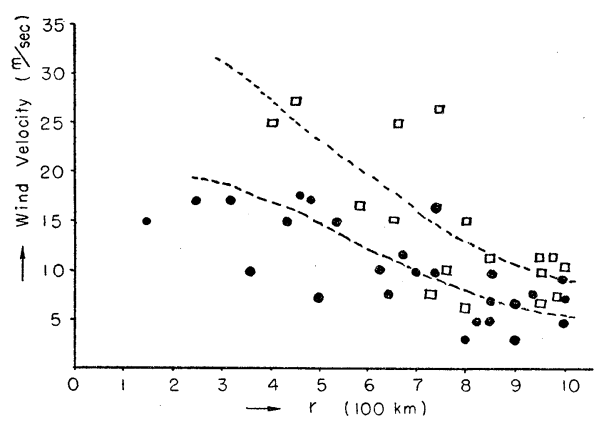

Fig. 6. The distribution of observed velocity on sea and on land respectively by synoptic data, at $0600 \mathrm{z} 12 \mathrm{th}$, in typhoon June.

Symbol $\square$ is data on sea, stations' data on land, ... the average distributional curve.

outer side are numerous comparably.

In this figure, symbol gives stations' data on land, and symbol $\square$ on sea.

In Fig. $7 \mathrm{a} \sim 7 \mathrm{e}$, the distribution of observed wind velocity, as the function of $r$ at surface, in the region of typhoon June is shown.

The data used was selected from only stations in solitary islands and headland, which are not disturbed by topography.

Further, the stations cited are situated on the typhoon center passage or in its neighourhood.

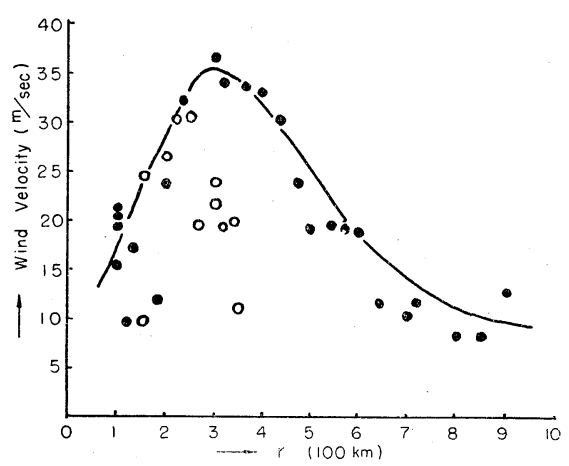

Fig. 7a. Variation of wind at Kusagakijima during typhoon June passage, in 12-14th. Symbol $\bigcirc$ : data before typhoon inversion, : data after.

Fig. 7a shows wind data at Kusagakijima during typhoon June passage, in 12-14th.

In this figure, symbol $\bigcirc$ gives data before typhoon inversion $(1500 \mathrm{z} 12 \mathrm{th}-0200 \mathrm{z} 13 \mathrm{th})$, and symbol data after $(0300 \mathrm{z} 13 \mathrm{th}-1500 \mathrm{z}$ 14 th).
Maximum wind velocity is $36 \mathrm{~m} \mathrm{sec}^{-1}$ at $r=300 \mathrm{~km}$, and seems closely relating to the calculated gradient wind velocity in Fig. 6c. The agreement can be said good when the height of this station 140.2 meters is considered.

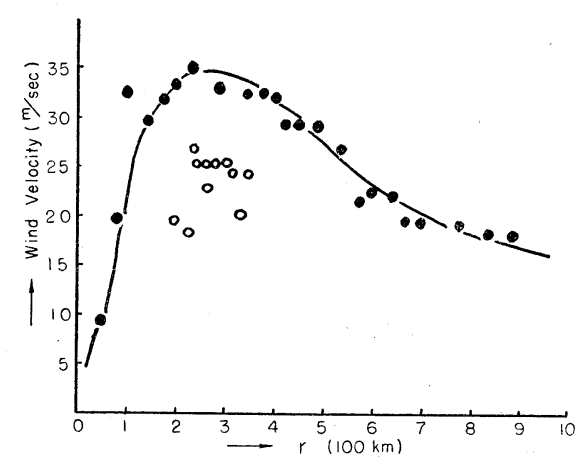

Fig. $7 \mathrm{~b}$. The variation of wind velocity at Satamisaki during the typhoon June, the station altitude being 60.2 meters, and the symbol being the same as in Fig. 7a.

Next, wind data at Satamisaki are shown in Fig. $7 \mathrm{~b}$, the symbol used being the same as in Fig. 7a.

From the data, the wind velocity distribution is found in fair agreement with the calculated value in Fig. $5 \mathrm{c}$ for $z=50 \mathrm{~m}$, referring the station altitude 60.2 meters, and the maximum wind velocity $35 \mathrm{~m} \mathrm{sec}^{-1}$ at $r=250 \mathrm{~km}$.

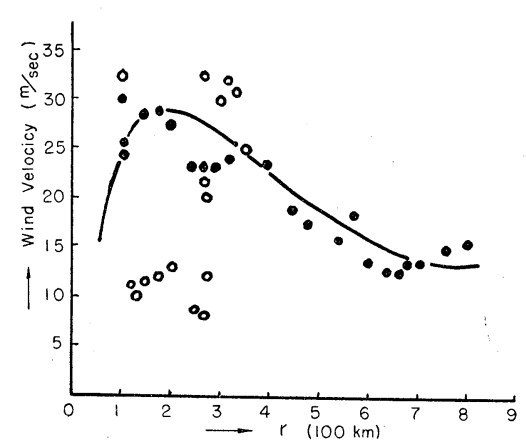

Fig. 7c. The variation of wind velocity at Toimisaki during 12 th to 14 th, the station altitude being 255 meters.

Fig. 7c shows wind data at Toimisaki, during $1500 \mathrm{z} 12$ th to $0300 \mathrm{z} 14 \mathrm{th}$, symbol $\bigcirc$ being data for $1500 z 12$ th $-0500 z$ 13th, and for $0600 \mathrm{z} 13$ th $-0300 \mathrm{z} 14$ th. 


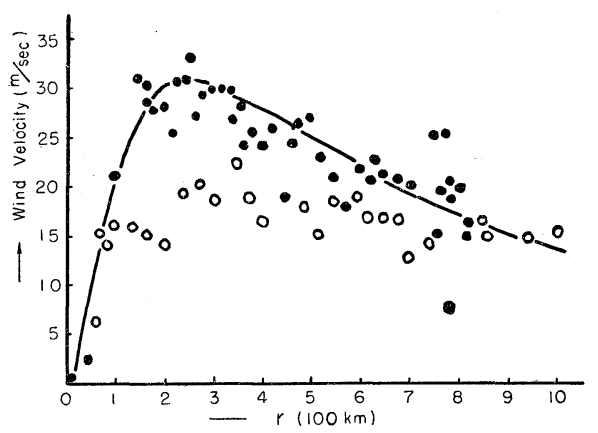

Fig. 7d. The variation of wind velocity at Yakushima during $11-14$ th, the station altitude being 15 meters.

Fig. 7d shows wind data at Yakushima, symbol $\bigcirc$ being data for $0200 z 11$ th $-0300 z$ 12 th, and for $0400 z 12-0300 z$ 14th.

When the center of typhoon arrived at Yakushima, the wind velocity weakened suddenly and became zero.

After it passed, wind velocity increased sharply again. And the maximum wind velocity attaind to $33 \mathrm{~m} \mathrm{sec}^{-1}$ at $r=250 \mathrm{~km}$, agreeing with Fig. 5b, $z=20$ meters.

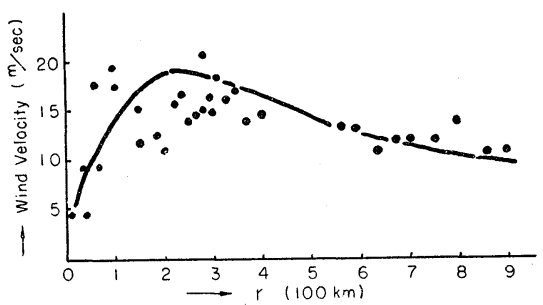

Fig. 7e. The variation of wind velocity at Makurazaki during typhoon June, the station altitude being 31 meters.

Fig. 7e shows the wind data at Makurazaki, the station altitude being 30 meters, and the wind velocity resembles to Fig. 6, where $z=20$ meters.

Table 1. Station position and altitude.

\begin{tabular}{l|l|l|c}
\hline Station name & $\begin{array}{c}\text { Lat. (N) } \\
\text { deg. } \\
\text { min. sec. }\end{array}$ & $\begin{array}{l}\text { Long. (E) } \\
\text { deg. } \\
\text { min. sec. }\end{array}$ & $\begin{array}{c}\text { Altitude } \\
(\mathrm{m})\end{array}$ \\
\hline Kusagakijima & $30^{\circ} 51^{\prime} 29^{\prime \prime}$ & $129^{\circ} 27^{\prime} 56^{\prime \prime}$ & 140.2 \\
Satamisaki & $30^{\circ} 51^{\prime} 19.5^{\prime \prime}$ & $130^{\circ} 39^{\prime} 43^{\prime \prime}$ & 60.2 \\
Toimisaki & $31^{\circ} 21^{\prime} 49^{\prime \prime}$ & $131^{\circ} 20^{\prime} 53^{\prime \prime}$ & 255.0 \\
Yakushima & $30^{\circ} 27^{\prime}$ & $130^{\circ} 30^{\prime}$ & 15 \\
Makurazaki & $31^{\circ} 16^{\prime}$ & $130^{\circ} 18^{\prime}$ & 31 \\
\hline
\end{tabular}

Maximum wind velocity is $21 \mathrm{~m} \mathrm{sec}^{-1}$ at $r=290 \mathrm{~km}$.

Next, the station position and altitude are given in Table 1.

Nextly, Fig. 8 shows the calculated wind velocity on land and sea respectively, in the region of typhoon June, at $0600 \mathrm{z} 12 \mathrm{th}$, using

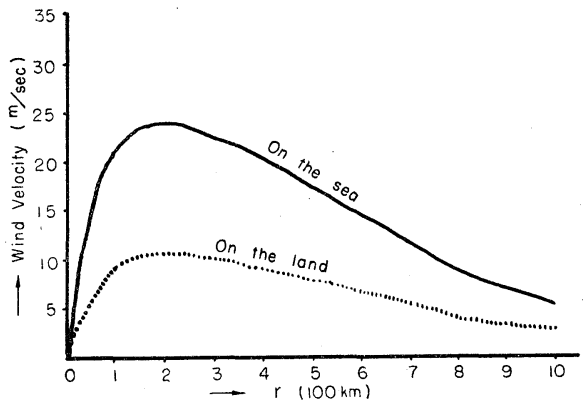

Fig. 8. The wind velocity on land and sea respectively, in the region of typhoon June, at $0600 \mathrm{z}$ 12th, using Takahashis' conversional graph (Fig. 9a) with the gradient wind velocity.

Takahashis' conversional graph (Fig. 9) with the gradient wind velocity.

In the figure, observational wind velocity on sea is shown larger than conversional value on sea.

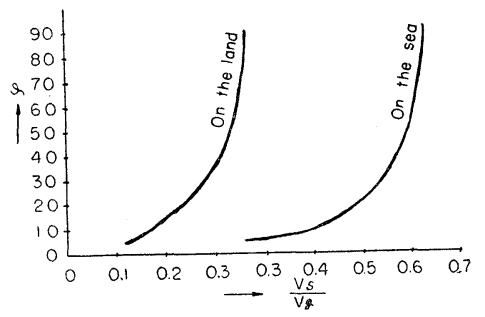

Fig. 9a. The relation between the ratio $V_{s} / V_{g}$ and the latitude by Dr. Takahashi,

$V_{s}:$ surface wind velocity,

$V_{g}:$ gradient wind velocity.

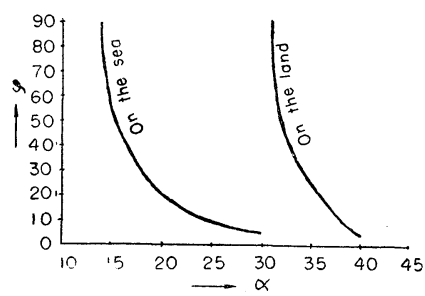

Fig. 9b. The relation between the angle $\alpha$, between the isobar and the surface wind, and the latitude. 
Fig. 9a is a graph to get wind velocity on sea and land, using the gradient wind velocity by Dr. Takahashis' method.

Fig. $9 \mathrm{~b}$ is a calculated graph to get the angle between the surface wind direction and isobar as a function of latitude.

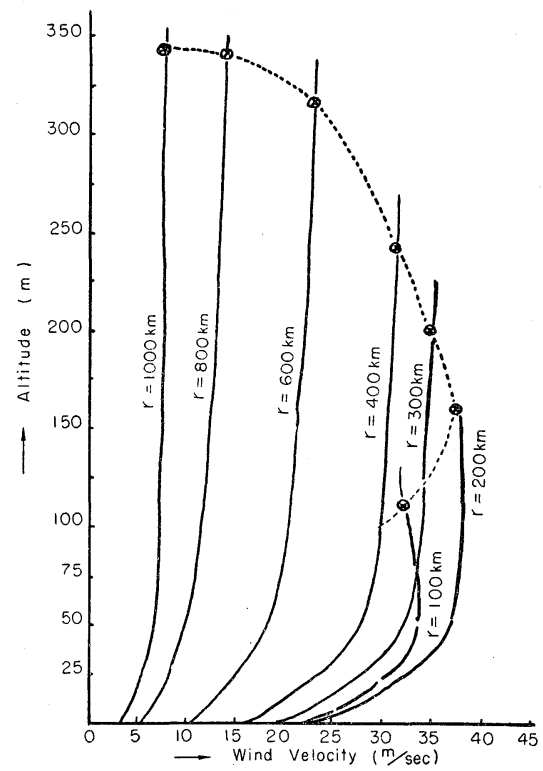

Fig. 10. The relation between the wind velocity and the altitude in the region of typhoon June at $0600 \mathrm{z} 12 \mathrm{th}$, using eq. (36), where the following values are used; $\rho=1.1 \cdot 10^{-3} \mathrm{~g} \mathrm{~cm}^{-3}, \quad m=1, \quad n=1$, $r_{1}=300 \mathrm{~km}, \Delta p=60 \mathrm{mb}, \varphi=27^{\circ}, \nu=0.3 \mathrm{~m}^{2}$ $\sec ^{-1}, x=50 \mathrm{~m}$.

Symaols $\otimes \cdots \cdots \otimes$ show the height of frictional influence.

Fig. 10 shows the relation between the calculated wind velocity and the altitude in the region of typhoon June, at $0600 \mathrm{z} 12 \mathrm{th}$, using eq. (36), where the following values are used;

$$
\begin{aligned}
& \rho=1.1 \cdot 10^{-3} \mathrm{~g} \mathrm{~cm}^{-3}, \quad m=1, \quad n=1, \\
& r_{1}=300 \mathrm{~km}, \quad \Delta p=60 \mathrm{mb}, \quad \varphi=27^{\circ}, \\
& \nu=0.3 \mathrm{~m}^{2} \mathrm{sec}^{-1}, \quad \chi=50 \mathrm{~m} .
\end{aligned}
$$

Here, the longitudinal axis gives the height and the transverse axis wind velocity.

Symbols $\otimes \cdots \cdots \otimes$ show the height of frictional influence. From the figure, the height is found very low in the region of this typhoon center.

Fig. 11 shows the vertical distribution of upper wind velocity and the calculated value by eq. (36) at Kagoshima and Itazuki.

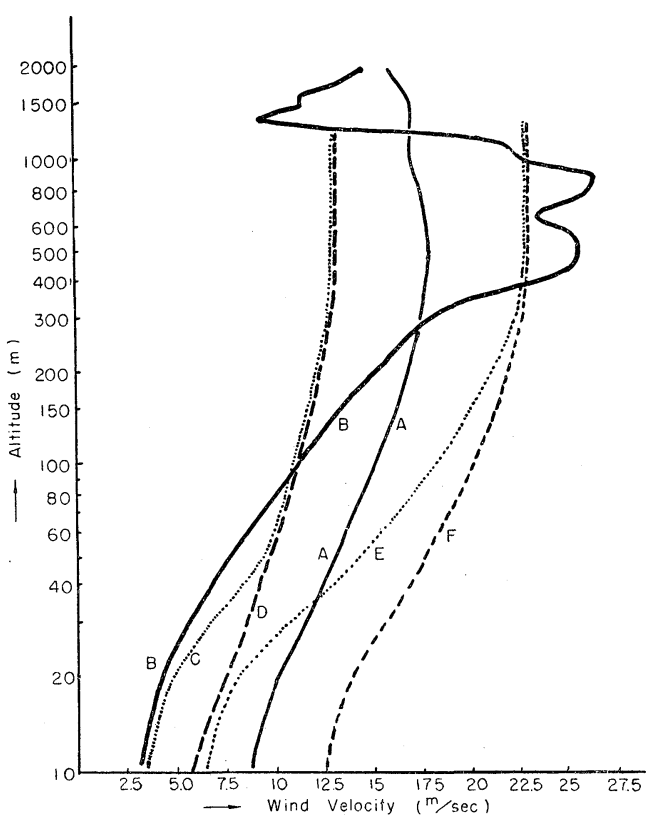

Fig. 11. The vertical distribution of wind velocity and the calculated value by eq. (36) at Kagoshima and Itazuki. The explanation for each curve is given in Table 2.

Table 2. Upper wind data and the calculated upper wind velocity at Kagoshima and Itazuki.

\begin{tabular}{c|cc}
\hline & \multicolumn{2}{|c}{ Remarks } \\
\hline A & Kagoshima upper wind data at $\begin{array}{c}0300 \mathrm{z} 12 \mathrm{th}, \\
r=550 \mathrm{~km} .\end{array}$ \\
B & Itazuki upper wind data at $0900 \mathrm{z}, \begin{array}{c}12 \mathrm{th}, \\
r=670 \mathrm{~km} .\end{array}$ \\
C & Values calculated by eq. $\begin{array}{c}(36) \\
x=10 \mathrm{~m}, r=800 \mathrm{~km} .\end{array}$ \\
D & $m=1, n=1$, & $x=50 \mathrm{~m}, r=800 \mathrm{~km}$. \\
E & $r_{1}=300 \mathrm{~km}^{2}$, & $x=10 \mathrm{~m}, r=600 \mathrm{~km}$. \\
F & $\nu=0.3 \mathrm{~m}^{2} \mathrm{sec}^{-1}$, & $x=50 \mathrm{~m}, r=600 \mathrm{~km}$. \\
\hline
\end{tabular}

The explanation for each curve is given in Table 2.

Then, the data at Kagoshima is found closely relating to the calculated curves $D$ and $F$, though the data are scanty in the lower layer from surface to 500 meters.

On the other hand, Itazukis' wind velocity, which was weak at the surface, increased much with height, attaining $26 \mathrm{~m} \mathrm{sec}^{-1}$ at the altitude $400 \mathrm{~m}$, and weakened with height over $900 \mathrm{~m}$.

This curve is slightly similar to $E$ curve 


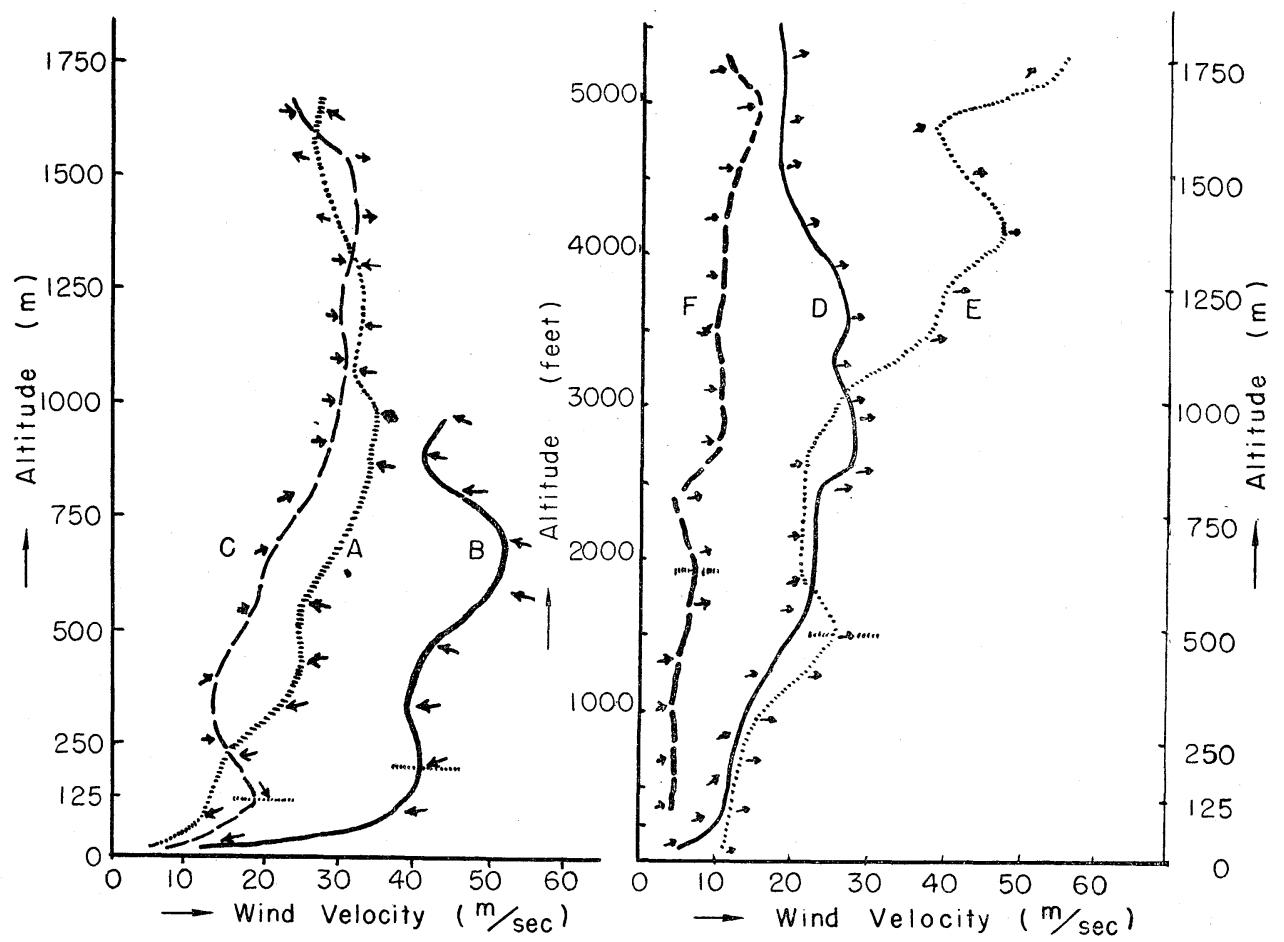

Fig. 12a. The vertical distribution of upper wind velocity in 13--14th at Itazuki, the wind direction at each height being plotted by arrow mark. The explanation for each curve is given in Table 3 .

from these upper data, and it seems that the height of frictional influence is about $500 \mathrm{~m}$ at Kagoshima $(r=550 \mathrm{~km})$ and about $550 \mathrm{~m}$ at Itazuki $(r=500 \mathrm{~km})$.

Fig. 12a shows the vertical distribution of upper wind by rawins data in 13-14th at Itazuki.

Wind direction at each height is plotted by arrow mark, wind direction $\mathrm{N} \downarrow, \mathrm{E} \leftarrow, \mathrm{S} \uparrow$, $\mathrm{W} \rightarrow$, and the explanation for each curve is given in Table 3.

Fig. $12 \mathrm{~b}$ shows the vertical distribution of

Table 3. Itazuki upper wind data.

\begin{tabular}{c|c|c|c}
\hline Curve & $\begin{array}{c}\text { Time and } \\
\text { Date }\end{array}$ & $\begin{array}{c}\text { The distance } \\
\text { from the typhoon } \\
\text { center } r\end{array}$ & $\begin{array}{c}\text { The height } \\
\text { of frictional } \\
\text { influence }\end{array}$ \\
\hline A & $0500 z 12 \mathrm{th}$ & $630 \mathrm{~km}$ & $400 \mathrm{~m}$ \\
B & $0900 z 13 \mathrm{th}$ & $180 \mathrm{~km}$ & $200 \mathrm{~m}$ \\
C & $1500 z 13 \mathrm{th}$ & $70 \mathrm{~km}$ & $120 \mathrm{~m}$ \\
D & $2100 \mathrm{z} 13 \mathrm{th}$ & $210 \mathrm{~km}$ & $80 \mathrm{~m}$ \\
E & $0300 z 14 \mathrm{th}$ & $510 \mathrm{~km}$ & $500 \mathrm{~m}$ \\
F & $0900 \mathrm{z} 14 \mathrm{th}$ & $820 \mathrm{~km}$ & $700 \mathrm{~m}$ \\
\hline
\end{tabular}

upper wind in 11-14th at Kagoshima, the explanation for each curve being given in Table 4.

Table 4. Kagoshima upper wind data.

\begin{tabular}{c|c|c|c}
\hline Curve & $\begin{array}{c}\text { Time and } \\
\text { Date }\end{array}$ & $\begin{array}{c}\text { The distance } \\
\text { from the typhoon } \\
\text { center } r\end{array}$ & $\begin{array}{c}\text { The height } \\
\text { of frictional } \\
\text { influence }\end{array}$ \\
\hline A & $1500 z 11 \mathrm{th}$ & $870 \mathrm{~km}$ & $1,200 \mathrm{~m}$ \\
B & $0300 z 12 \mathrm{th}$ & $550 \mathrm{~km}$ & $500 \mathrm{~m}$ \\
C & $2100 z 12 \mathrm{th}$ & $300 \mathrm{~km}$ & $200-500 \mathrm{~m}$ \\
D & $0700 z 13 \mathrm{th}$ & $60 \mathrm{~km}$ & - \\
E & $1100 z 13 \mathrm{th}$ & $120 \mathrm{~km}$ & $0 \mathrm{~m}$ \\
F & $1500 z 13 \mathrm{th}$ & $250 \mathrm{~km}$ & $0 \mathrm{~m}$ \\
G & $2100 z 13 \mathrm{th}$ & $530 \mathrm{~km}$ & $500 \mathrm{~m}$ \\
\hline
\end{tabular}

Symbol......shows the height of frictional influence in Figs. $12 \mathrm{a}$ and $12 \mathrm{~b}$.

Fig. 13 shows the relation between the height of frictional influence $D$ and the distance from the center $r$, using the upper data at Kagoshima and Itazuki, in typhoon June. 


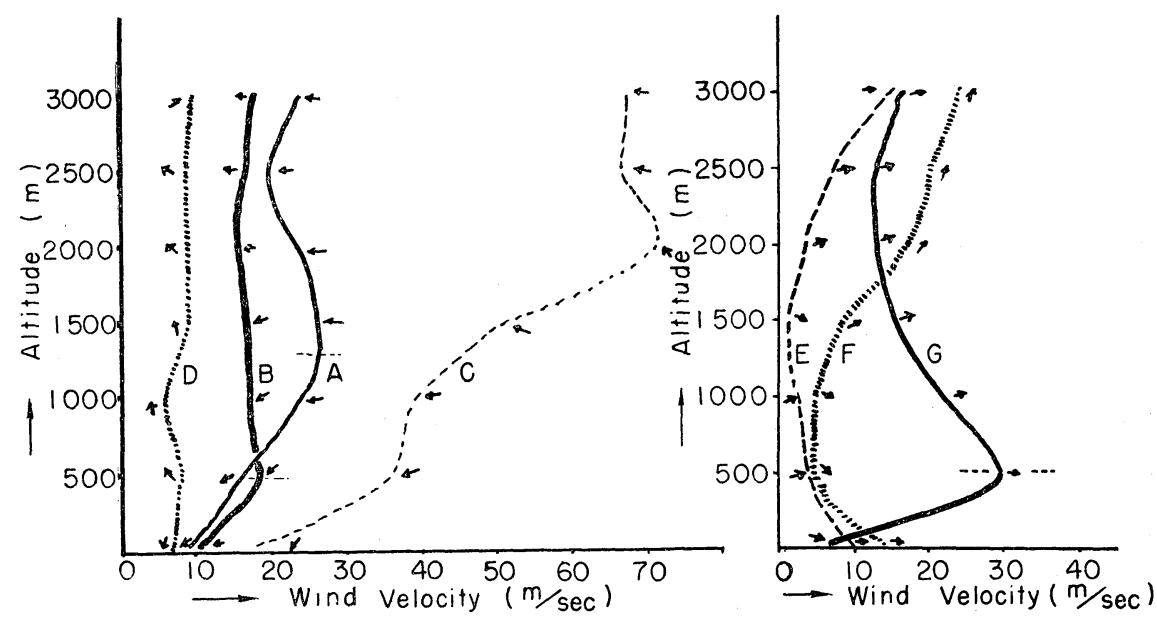

Fig. 12b. The vertical distribution of upper wind velocity in 11-14th at Kagoshima. Symbol --- showing the height of frictional influence, and the explanation for each curve being given in Table 4 .

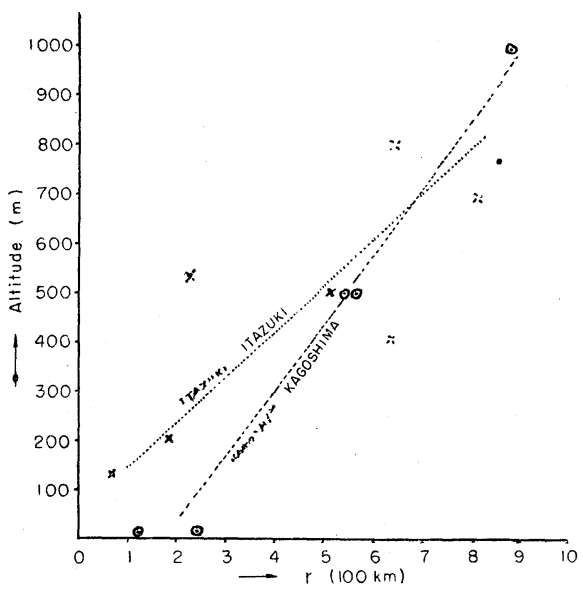

Fig. 13. The relation between the height of frictional influence $D$ and the distance from the center $r$, using the upper data at Kagoshima and Itazuki in typhoon June, symbols $\times$, giving the height of frictional influence at Itazuki and Kagoshima respectively.

Symbols $\times$, $\odot$ give the frictional influence at Itazuki and Kagoshima respectively.

From this figure, it is found that the height of frictional influence is about $0-150$ meters in this typhoon center, incresing gradually to outer side, and attaining about $1000-1200$ meters in the most outer region.

\section{Conclusion and remarks}

In this report, the equation of pressure distribution of exponential type was used, the circulars in the region of typhoon being assumed.

And from it, the relative vorticity, the height of frictional influence, and the distribution of wind velocity were obtained as the function of the height $z$ and the distance from the center $r$.

And calculated values were compared with the synoptic data, taking typhoon June for an example.

Typhoon June has been observed developing most at far off of south Kyushu.

And when she approached to Kyushu, she shallowed its center depth and declined, and the region of center became spread in a considerable extent.

Then, the pressure distribution was got accurately and simply by eq. (7).

The typhoon June is a good example for the equation of pressure distribution (1), as $a_{1}=1, m=1$ and $n=1$ are suited for synoptic data.

(1) The constants which decide the form of pressure distribution in the region of typhoon changed largely and obviously during the period from the developing to the declining.

(2) The value of relative vorticity showed $4 \cdot 10^{-4} \mathrm{sec}^{-1}$ at $r=100 \mathrm{~km}$, decreased gradually as proceeding to outer region, became zero at $r=500 \mathrm{~km}$, and showed small negatives in 
more outer regions. The vorticitiy distribution by this method shows the similar tendency as the case of wind distribution.

(3) The eddy frictional coefficient $\nu$, in the region of typhoon, is considered as small value as about $0.3-0.5 \mathrm{~m}^{2} \mathrm{sec}^{-1}$, in the lower layer (height $0-500 \mathrm{~m}$ ).

If the value of $\nu$ is assumed to be $50 \mathrm{~m}^{2}$ $\mathrm{sec}^{-1}$, then the calculated wind velocity in the lower layer becomes too small.

(4) The height of frictional influence in the region of typhoon is considered much lower than that of the general atmospheric condition (height $1000-1500 \mathrm{~m}$ ).

And it is considered that this height is about $0-200 \mathrm{~m}$ in the typhoon center, increasing gradually to outer sides, and attaining about 1000 meters or more at the most outer sides.

These conclusions ascertain that the vertical distribution of upper wind and wind velocity at solitary islands closely relate to the gradient wind velocity in the region of typhoons center.

In the present paper, the relation between the theoretical value and the observational value of wind velocity is examind, taking typhoon June for an example.

In future, the author will test to apply the method for more examples of typhoons, and will endeavour after the generality of the method.

And further, the author wants to study the relations with the other meteorogical elements in the region of the typhoon in detail.

\section{Acknowledgment}

The author wishes to express his sincere thanks to Mr. S. Minegishi, the investigator at the inquiry section of Fukuoka Meteorological Observatory, for his guidance.

\section{References}

1. Syono, S. (1944): Study of atmospheric inversion (9). Journ. Met. Soc. Japan. 22, No. 12.

2. Fujita, T. (1952): Pressure distribution within typhoon. Kyushu Institute of Technology. Tobata.

3. Musuda, Y. and Kasahara, A. (1956): The theory of typhoon.

4. Gambo, K. and Kasahara, A. (1952): Note on the motion of a rotating solid cylinder on a rotating earth. Journ. Met. Soc. Japan. 30, No. 4.

5. Ohtani, T. and Takahashi, K. (1946): Theory of the weather forecasting. pp. 202-204.

6. Takahashi, S., Watanabe, T., Kubota, S., Ando, T. and Nakamura, N. (1951): The structure and the energy of typhoon. Journ. Met. Soc. Japan. 29, No. 3.

7. Syono, S. (1954): Introduction of dynamic meteorology. pp. 321-329.

8. Phil-Trans (1915): Roy. Soc. A. 215. I.

9. Syono, S. (1951): On the motion of a vortex in a nonuniform pressure field. Pap. Met. Geophys. 2, pp. 117-128.

10. Yanai, M. (1958): On the changes in the thermal and wind structure in a decaying typhoon. Journ. Met. Soc. Japan. 36, No. 4.

11. Tomitaka, S. (1959): On the distribution of the wind velocity in the typhoon region. Jour. Met. Res. II, II. 


\title{
台風圏内の気象要素の分布（第 1 報）
}

\author{
富高四郎 \\ (福岡管区気象台)
}

台風圈内の海面気圧を円型分布とし，指数項からなる精度のよい一般的な分布式を用いると，傾度風速，渦度分 布が求まる。

定常で, 偏向力, 気圧傾度, 摩擦力の項からなり, 円壔座標で表わされた二次元の大気の運動方程式の一般解飞, 上述の值を代入し，渦粘性係数，地表風の状態の常数值をさめることにより，台風圈内の風の分布を中心距離，高 度の函数として, 求めることができる。また摩擦高度, 上昇速度, 渦動性降雨量も求まる。

この算出方法のテストとして，1954 年九州飞襲来した猛台風第 12 号とついて，実地計算を行つた。これから， 相対渦度も風の分布から直接求まるものと，同じ程度で，内域は正の值で大きく，外域は負の小さい值を示した。

また渦粘性係数は，台風圈内の下層大気中では，一般飞考えられているょりもかなり小さい值 $0.3 \mathrm{~m}^{2} \mathrm{sec}^{-1}$ 程度 と仮定してみた。

このとき，台風圈内の各地の地表に招ける風速の水平分布，地勢の影響の小さい海上の孤島観測所の風速変化， 拉よび鹿児島，板付の上層風速の垂直分布は，上述の理論による算出值と，かなりょい一致を示した。

今後多くの台風についてのテストルより，この方法の普偏化をはかると共に，さらに上昇速度，渦動性降雨量な どの気象要素算出の実用化が重要である。 